\title{
Mikroblødninger i hjernen
}
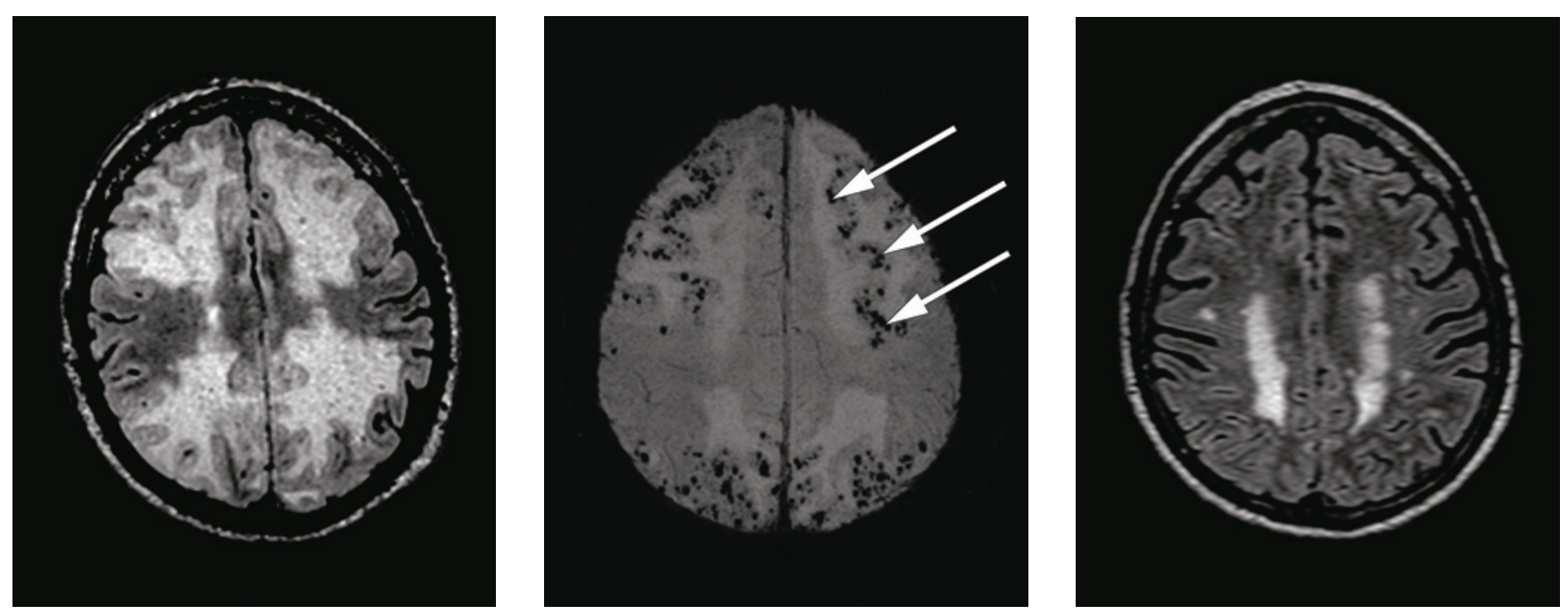

En mann i 70-årene ble innlagt i nevrologisk avdeling etter en episode med synkope og mulig krampeanfall. Han hadde familiær belastning med karsykdom, hypertensjon og insulinbehandlet diabetes. Pasienten hadde fått diagnosen Alzheimers sykdom et år tidligere, og det ble derfor startet opp med donepezil. Noen uker etter utskrivning fra avdelingen ble han gradvis mer ustø og fikk dårligere språk. Han ble reinnlagt etter en drøy måned, desorientert og med krampeanfall.

MR caput ble utført etter reinnleggelsen. FLAIR-bilder viste utbredt ødem $\mathrm{i}$ begge storehjernehemisfærer (bildet til venstre). Suseptibilitetsvektede MR-bilder (SWI), spesielt følsomme for blodprodukter, viste tallrike mikroblødninger $i$ affiserte områder (bildet i midten). Mikroblødningene ble tolket som cerebral amyloid angiopati. Det ble tatt EEG, som viste langsom epileptiform aktivitet. Temporalisbiopsi var positiv. Sett i sammenheng med sykehistorien passet bildefunnene best med cerebral amyloid angiopati av inflammatorisk type. Det ble igangsatt behandling med prednisolon, med god effekt. Senere ble det gitt metotreksat og antiepileptisk behandling med Orfiril.

MR-kontroll etter seks uker viste tilbakegang av ødemet i hjerneparenkymet (bildet til høyre). Pasienten var da betydelig bedre, dog ikke helt restituert.

Cerebral amyloid angiopati er en sykdom med avleiring av $\beta$-amyloid i veggen til små

og mellomstore cerebrale arterier og en viktig årsak til hjerneblødning hos eldre. Hyppigheten øker med økende alder. En liten andel pasienter med sykdommen har cerebral amyloid angiopati av inflammatorisk type, med inflammatoriske forandringer i karveggen eller perivaskulært $(1,2)$. Tilstanden kan gi et subakutt eller akutt klinisk bilde med kognitiv svikt, nevropsykiatriske symptomer, kramper og hodepine. Inflammasjonen og ødemet går tilbake med immunsuppresjonsbehandling, mens mikroblødningene består $(1,2)$. Siden mikroblødningene er vanskelig å oppdage med standard MRsekvenser, bør bildesekvenser som er følsomme for blodprodukter inkluderes i utredningen av kognitiv svikt hos eldre.

Pasienten har gitt samtykke til at artikkelen blir publisert.

\section{Anniken Haslund}

anniken.haslund@vestreviken.no

Avdeling for bildediagnostikk

Drammen sykehus

\section{Kjell Arne Kvistad}

Klinikk for bildediagnostikk

St. Olavs hospital

\section{Karl-Friedrich Amthor}

Nevrologisk avdeling

Drammen sykehus

\section{Cecilie Kaufmann}

Revmatologisk avdeling

Drammen sykehus
Anniken Haslund (f. 1967) er spesialist i radiologi og seksjonsoverlege.

Forfatter har fylt ut ICMJE-skjemaet og oppgir ingen interessekonflikter.

Kjell Arne Kvistad (f. 1960) er dr.med., spesialist i radiologi og seksjonsoverlege.

Forfatter har fylt ut ICMJE-skjemaet og oppgir ingen interessekonflikter.

Karl-Friedrich Amthor (f. 1950) er dr.med., spesialist i nevrologi og seksjonsoverlege.

Forfatter har fylt ut ICMJE-skjemaet og oppgir ingen interessekonflikter.

Cecilie Kaufmann (f. 1957) er spesialist i revmatologi og overlege.

Forfatter har fylt ut ICMJE-skjemaet og oppgir ingen interessekonflikter.

Litteratur

1. Castro Caldas A, Silva C, Albuquerque $L$ et al. Cerebral amyloid angiopathy associated with inflammation: Report of 3 cases and systematic review. J Stroke Cerebrovasc Dis 2015; 24: 2039-48.

2. Salvarani C, Morris JM, Giannini $C$ et al. Imaging findings of cerebral amyloid angiopathy, $A \beta$-related angiitis (ABRA), and cerebral amyloid angiopathyrelated inflammation. Medicine (Baltimore) 2016; 95: e3613.

Mottatt 12.8. 2016, første revisjon innsendt 24.10. 2016, godkjent 14.11. 2016. Redaktør: Tor Rosness. 